\title{
Productivity Enhancement of Rapeseed-Mustard through Front Line Demonstration in Seoni District of Madhya Pradesh, India
}

\author{
Naresh Kumar Bisen ${ }^{1}$, N. K. Singh ${ }^{2 *}$ and R. S. Solanki ${ }^{1}$ \\ ${ }^{1}$ Raja Bhoj Collage of Agriculture, Waraseoni, Balaghat, JNKVV, Jabalpur, M.P. India \\ ${ }^{2}$ Krishi Vigyan Kendra, Seoni, JNKVV, Jabalpur, M.P. India \\ *Corresponding author
}

\section{A B S T R A C T}

\begin{tabular}{l} 
Ke y w o r d s \\
Mustard, \\
$\begin{array}{l}\text { Demonstration, } \\
\text { Gap analysis, } \\
\text { Economics, } \\
\text { Grain yields }\end{array}$ \\
\hline Article Info \\
\hline $\begin{array}{l}\text { Accepted: } \\
15 \text { March } 2020 \\
\text { Available Online: } \\
\text { 10 April 2020 }\end{array}$ \\
\hline
\end{tabular}

The present study was carried out to know that the yield gaps between improved package and practices and farmers practice of rapeseed-mustard crop. Front line demonstrations on mustard variety PusaTarak were conducted at farmers' fields in district Seoni (Madhya Pradesh) during Rabi seasons of the year 2016-17 \& 2017-18 On two years overall average basis about 46.56 per cent higher grain yield was recorded under demonstrations than the farmers' traditional practices. The extension gap, technology gap and technology index were $575.5 \mathrm{~kg} / \mathrm{ha}, 184.5 \mathrm{Kg} / \mathrm{ha}$ and $9.24 \%$, respectively. An additional investments of Rs.1165 per ha coupled with scientific monitoring of demonstrations and non-monetary factors resulted in additional return of Rs. 17265 per ha. On two years overall average basis Incremental benefit: Cost ratio was found as 14.94.By conducting front line demonstration of proven technologies, yield potential from rapeseed mustard cultivation can be enhanced to a great extent with increase in the income level of the farming community.

\section{Introduction}

The Indian agriculture is considered to be the backbone of Indian economy. The agricultural sector is the largest employer in India's economy and employed $49 \%$ of its total workforce in 2014 but contributes to a declining share of its GDP (17\% in 201314). A large number of important industries like jute, textiles, edible oils, tobacco, sugar, etc. receive the raw materials produced by agriculture sectors. Edible oilseeds are an essential part of Indian agriculture and contribute more than 10 percent to agriculture GDP. Soybean, groundnut and rapeseedmustard are the major oilseed crops in India contributing nearly $79 \%$ and $88 \%$ to its total acreage and production, respectively. During 2012-13, rapeseed-mustard contributed 24.2 $\%$ to the total oilseeds production. Globally, 
India account for $19.29 \%$ and $11.27 \%$ of the total area and production of mustard (USDA 2013).

Mustard seed is the second most important oil seed crop in India after soybean. It accounts for nearly $20-22 \%$ of the total oilseeds produced in the country. Mustard seed is grown with a different consumption pattern in the country. Indian mustard is mainly used for extraction of mustard oil while black mustard is mainly used as a spice. White mustard is used as fodder crop or as green manure. India is the fourth producer of mustard seed contributing to around $11 \%$ of world's total production. The production in India has been witnessing an increasing trend since the 20012014 decade due to increasing usage of mustard seed oil in food. Moreover, strong domestic demand for mustard seed oil was also one of the reasons for rise in production. European Union (27\%) is the leading producer of mustard seed in the world accounting for $35 \%$ of the world production followed by Canada (21\%), China (22\%) and India (11\%) (Mustard Crop Survey Report 2014-15). In India, mustard seed is mainly grown in North West parts of India. Rajasthan and Uttar Pradesh are the major producing States in the country. The other significant producers are Madhya Pradesh, Haryana, Gujarat, West Bengal and Assam. Mustard Seed is a Rabi season crop sown during OctNov and harvested during March -April. Marketing season starts from March and end during Feb. Rapeseed-mustard is a multiple use crop. Besides, its oil value, its seeds are also used as condiments in preparation of pickles and flavouring curries and vegetables. Oil and fat play a significant role in the human dietary system as well as the economy of the people. The oil is utilized for human consumption throughout India in cooking \& frying. The leaves of young plants are used as a green vegetable as they supply enough sulphur minerals in the diet. The oil cakes are used as cattle feed \& manures. Considering the importance of a rapeseed-mustard group of the crop in the Indian economy is the urgent need for undertaking the basic \& strategic research for stabilizing and increasing the production \& productivity of mustard in our country.

The available agricultural technology does not serve its purpose till it reaches and adopted by its ultimate users, the farmers. Technology transfer refers to the spread of new ideas from originating sources to ultimate users (Prasad et al., 1987). Conducting of frontline demonstrations on farmer's field help to identify the constraints and potential of the rapeseed-mustard in specific area as well as it helps in improving the economic and social status of the farmers. The aim of the front line demonstration is to convey the scientific technical message to farmers that if they use recommended package and practices then the yield of this crop can be easily doubled than their present level. In view of the importance of demonstrations in crop productivity and continuously getting feedback of problems and constraints faced by the farmers, front line demonstration with full skill and knowledge with scientists have been taken up in rapeseed-mustard also. Keeping the importance of FLDs, the KVK, Seoni conducted demonstrations on oilseed crops mustard at farmers field under irrigated situations in Rabi 2016-17 \& 2017-18. The objectives were as follows:

To exhibit the performance of recognised \& recommended high yielding Mustard varieties with full recommended package of practices for harvesting higher crop yields.

To compare the yield levels of local check (farmers' field) and FLD fields.

To collect feedback information for further improvement in research and extension programme. 


\section{Materials and Methods}

Front line demonstrations on Mustard were conducted at farmers' field in district Seoni (Madhya Pradesh) to assess its performance during Rabi seasons of the year 2016-17 \& 2017-18. Before laying down FLDs, PRA survey was conducted to identify the farmers practices (FP) and interventions were finalized on that basis. Major constraints were identified included the higher seed rate without treatment, delayed sowing time, defective method of sowing, imbalance use of chemical fertilizer, no or less plant protection measures, no weed management and use of old varieties in Seoni district. Keeping in view of above factors, farmers having varied size holdings from each village, were selected. The interventions viz. optimum seed rate with treatment, normal sowing time, sowing in lines, balance use of chemical fertilizer, use of plant protection measures, weed management and use of recent varieties were applied in the demonstrated fields along with control i.e. farmer's practice (Table 1) Above mentioned techniques (FLDs) were demonstrated in 10 ha area along with farmers practice. Mustard crop was sown during $2^{\text {nd }}$ week of October at all demonstration sites. Yield data were recorded by using crop cutting survey. Locality, average weather parameters and soil characteristics of the district are presented in Table 2.

Each demonstration were using recommended package of practices and the farmers were provided quality seed of Mustard variety EJ9912-13 (PusaTarak) during all the years of the study. The demonstrations on farmers' fields were regularly monitored by Krishi Vigyan Kendra, Seoni scientists right from sowing to harvesting. The grain yield of demonstration crop was recorded \&analyzed. Different parameters as suggested by Yadav et al., (2004) were used for calculating gap analysis, costs and returns. The detail of different parameters is as follows:

Extension gap $=$ Demonstration yield Farmers practice yield

Technology gap $=$ Potential yield Demonstration yield

Technology index $=\frac{\text { Technology gap }}{\text { Potential yield }} \times 100$

Additional cost $=$ Cost of cultivation in demonstration-cost of cultivation in farmer practice

Additional return $=$ Gross return in demonstration - gross return in farmer practice

Effective gain $=$ Additional return Additional cost

Incremental $\mathrm{B}: \mathrm{C}$ ratio $(I C B R)=$ Additional return

Additional cost

\section{Results and Discussion}

\section{Grain yield}

The increase in grain yield under demonstration was 31.21 to 62.42 per cent than farmers' local practices. On the basis of two years, 46.56 per cent yield advantage was recorded under demonstrations carried out with improved cultivation technology as compared to farmers' traditional way of Mustard cultivation.

\section{Gap analysis}

An extension gap of $392-759 \mathrm{~kg} / \mathrm{ha}$ was found between demonstrated technology and farmers practices during different two years and on average basis the extension gap was $575.5 \mathrm{~kg} / \mathrm{ha}$ (Table 3). The extension gap was lowest (392 kg/ha) during 2017-18 and was 
highest (759 kg/ha) during 2016-17. Such gap might be attributed to adoption of improved technology in demonstrations which resulted in higher grain yield than the traditional farmers practices. Wide technology gap were observed during different years and this was lowest (21 kg/ha) during 2016-17 and was highest (348 kg/ha) during 2017-18. On two years average basis the technology gap of total 15 demonstrations was found as 184 $\mathrm{kg} / \mathrm{ha}$. The difference in technology gap during different years could be due to more feasibility of recommended technologies during different years. Similarly, the technology index for all the demonstrations during different years were in accordance with technology gap. Higher technology index reflected the inadequate proven technology for transferring to farmers and insufficient extension services for transfer of technology.

Technology index shows the feasibility of the variety at the farmer's field. The lower the value of technology index more is the feasibility. Table 3 revealed that the technology index value was 9.24. The findings of the present study are in line with the findings of Sawardekar et al., (2003), Dhaka et al., (2016), Kumari et al., (2017), Mahadik and Talathi (2016), Singh and Kumar (2017) and Kumar 2017

\section{Economic analysis}

Different variables like seed, fertilizers, bio fertilizers and pesticides were considered as cash inputs for the demonstrations as well as farmers practice and on an average an additional investment of Rs. 1165 per ha was made under demonstrations. Economic returns as a function of grain yield and MSP sale price varied during different years. Maximum returns (Rs. 22770 per ha) during the year 2016-17 was obtained due to higher grain yield.. These results are in line with the findings of Yadav et al., (2016), Meena et al., (2016), Morwal et al., (2018), Meena and Dudi (2012), Dhaliwal et al., (2018), Dhaka et al., (2016) and Pathak (2018). The higher additional returns and effective gain obtained under demonstrations could be due to improved technology, non-monetary factors, timely operations of crop cultivation and scientific monitoring. The lowest and highest incremental benefit : cost ratio (IBCR) were $13.38 \& 16.50$ in 2017-18 and 2016-17, respectively (Table 4) depends on produced grain yield and MSP sale rates. Overall average IBCR was found as 14.94 Similar results were also reported by Meena and Singh (2017), Dhaka et al., (2016), Rathore et al., (2016), Meena and Singh (2017) and Morwal et al., (2018) in wheat crops.

Table.1 Comparison between demonstrations package and existing farmers practice

\begin{tabular}{|c|c|c|}
\hline \multirow[t]{2}{*}{ Particulars } & \multicolumn{2}{|c|}{ Rapeseed-mustard } \\
\hline & Demonstrations package & Farmers Practice \\
\hline Farming situation & Soybean-Mustard & Soybean-Mustard \\
\hline Variety & PusaTarak & Old variety \\
\hline Time of sowing & October $2^{\text {nd }}$ week & $1^{\text {st }}$ and $2^{\text {nd }}$ week of November \\
\hline Method of sowing & Line Sowing & Broadcasting \\
\hline Seed rate & $5 \mathrm{~kg} / \mathrm{ha}$ & $7-8 \mathrm{~kg} / \mathrm{ha}$ \\
\hline Fertilizer dose & 80:40:40, N:P:K/ha & Nil/without recommendation \\
\hline Plant protection & $\begin{array}{l}\text { Seed treatment and spray of } \\
\text { insecticide if required }\end{array}$ & $\begin{array}{l}\text { Seed treatment is not done, rarely } \\
\text { use of insecticide }\end{array}$ \\
\hline $\begin{array}{l}\text { Weed } \\
\text { management }\end{array}$ & $\begin{array}{l}\text { Spray of } 1.5 \mathrm{~kg} / \mathrm{ha} \text { Pendamethalin } \\
\text { herbicide }+ \text { one hand weeding }\end{array}$ & Only one hand weeding \\
\hline
\end{tabular}


Table.2 Characteristic of experimental site of Seoni district

\begin{tabular}{|l|c|}
\hline Parameters & Seoni District \\
\hline Latitude & $22.08^{\circ} \mathrm{N}$ \\
\hline Longitude & $79.53^{\circ} \mathrm{E}$ \\
\hline Altitude & $611 \mathrm{~meter}$ \\
\hline Annual rainfall (Average) $\mathbf{~ m m}$ & $1384 \mathrm{~mm}$ \\
\hline Maximum temperature $^{\mathbf{0}} \mathrm{C}$ & $41^{\circ} \mathrm{C}$ \\
\hline Minimum temperature $^{\mathbf{0}} \mathrm{C}$ & $11.7^{\circ} \mathrm{C}$ \\
\hline Soil type & Shallow \& Medium Black \\
\hline
\end{tabular}

Table.3 Grain yield and gap analysis of front line demonstrations on Mustard at farmers field

\begin{tabular}{|l|c|l|l|l|c|c|c|c|c|}
\hline Year & Demo. & Variety & $\begin{array}{c}\text { Potential } \\
\text { Yield } \\
\text { (Kg/ha) }\end{array}$ & $\begin{array}{c}\text { Demo. } \\
\text { Yield } \\
\text { (Kg/ha) }\end{array}$ & $\begin{array}{c}\text { Farmers } \\
\text { Practice Yield } \\
\text { (Kg/ha) }\end{array}$ & $\begin{array}{c}\text { Increase } \\
(\mathbf{\%})\end{array}$ & $\begin{array}{c}\text { Extension } \\
\text { gap } \\
(\mathbf{K g} / \mathbf{h a})\end{array}$ & $\begin{array}{c}\text { Technology } \\
\text { gap (Kg/ha) }\end{array}$ & $\begin{array}{c}\text { Technology } \\
\text { index }(\mathbf{\%})\end{array}$ \\
\hline $\mathbf{2 0 1 6 - 1 7}$ & 5 & $\begin{array}{l}\text { Pusa } \\
\text { Tarak }\end{array}$ & 1996 & 1975 & 1216 & 62.42 & 759 & 21 & 1.05 \\
\hline $\mathbf{2 0 1 7 - 1 8}$ & 10 & $\begin{array}{l}\text { Pusa } \\
\text { Tarak }\end{array}$ & 1996 & 1648 & 1256 & 31.21 & 392 & 348 & 17.43 \\
\hline Average & 8 & $\begin{array}{l}\text { Pusa } \\
\text { Tarak }\end{array}$ & 1996 & 1811.5 & 1236 & 46.56 & 575.5 & 184.5 & 9.24 \\
\hline
\end{tabular}

Table.4 Economic analysis of front line demonstrations on Mustard at farmers field

\begin{tabular}{|c|c|c|c|c|c|c|c|c|c|}
\hline \multirow[t]{2}{*}{ Year } & \multicolumn{2}{|c|}{$\begin{array}{c}\text { Cost of } \\
\text { cultivation } \\
\text { (Rs/ha) }\end{array}$} & \multirow{2}{*}{$\begin{array}{l}\text { Additional } \\
\text { cost in } \\
\text { Demo. } \\
\text { (Rs./ha) }\end{array}$} & \multirow{2}{*}{$\begin{array}{c}\text { Sale } \\
\text { price } \\
\text { (MSP) } \\
\text { of } \\
\text { (Rs./qtl.) }\end{array}$} & \multicolumn{2}{|c|}{$\begin{array}{l}\text { Gross Return } \\
\text { (Rs/ha) }\end{array}$} & \multirow{2}{*}{$\begin{array}{l}\text { Additional } \\
\text { return in } \\
\text { Demo. } \\
\text { (Rs./ha) }\end{array}$} & \multirow[t]{2}{*}{$\begin{array}{c}\text { Effective } \\
\text { gain } \\
\text { (Rs./ha) }\end{array}$} & \multirow[t]{2}{*}{ IBCR } \\
\hline & Demo. & FP & & & Dem & CD & & & \\
\hline 2016-17 & 13150 & & & 3000 & 59250 & & & & 16.50 \\
\hline 2017-18 & 12850 & 1900 & & 3000 & 49440 & 37 & 11760 & & 13.38 \\
\hline Average & 13000 & 11835 & 1165 & 3000 & 54345 & 37080 & 17265 & 16100 & 14.94 \\
\hline
\end{tabular}

Demo.=Demonstration, $\mathrm{FP}=$ Farmers practice

Front line demonstration program was effective in changing attitude, skill and knowledge of improved / recommended practices of Mustard cultivation including adoption. This also improved the relationship between farmers and scientists and built confidence between them. Favourable benefit cost ratio itself explanatory of economic viability of the demonstration and convinced the farmers for adoption of intervention imparted. The demonstration farmers acted also as primary source of information on the improved practices of Mustard cultivation and also acted as source of good quality pure seeds in their locality and surrounding area for the next crop. The concept of Front line demonstration may be applied to all farmer categories including progressive farmers for speedy and wider dissemination of the recommended practices to other members of the farming community. This will help in the removal of the cross-sectional barrier of the 
farming population. The yield gap in mustard can be overcome, through the wide publicity of the improved practices mustard cultivation by use of various extensions methodologies including Front Line Demonstrations as one of the most important method to show the result of improved practices.

\section{References}

Dhaka BL, Bairwa RK and Ram B. 2016. Productivity and profitability analysis of black gram (Cv. PU 31) at farmer's field in humid south eastern plain of Rajasthan. J Food Legume 29: 71-74.

Dhaliwal, NS, Sandhu GS and Sharma K. 2018. Evaluation of Frontline Demonstrations on rapeseed (Brassica napus L.) in south western district of Punjab. Journal of Oilseed Brassica 9: 68-71.

Kumar PR.2017. Enhancing production and productivity of Oilseed Brassica: Research need for $21 \mathrm{st}$ century. J Oilseed Brassica 8: 207.

Kumari K, Pyasi VK and Sharma A. 2017. Impact of Front Line Demonstration (FLD) on Area and Productivity of Wheat Growers in Jabalpur District of Madhya Pradesh, India. Int J CurrMicrobiol and ApplSci 6: 22372242.

Mahadik RP and Talathi MS. 2016. Impact of frontline demonstrations organized by Krishi Vigyan Kendra, Roha. Indian J Ext Edu Rural Dev 24:162-165.

Meena ML and Dudi A. 2012. On Farm Testing of gram (Cicerarietinum L.) cultivation for site specific assessment under rainfed condition of western Rajasthan. Indian Res J Ext Edu 48: 9397.

Meena M L and Singh D. 2017. Increasing wheat yield through frontline demonstration in Pali district of Rajasthan. Wheat and Barley Res 10:
$52-58$.

Meena M.L. and Dudi A.2018. Boosting the mustard production technology through frontline demonstration in Pali district of Rajasthan. J Oilseed Brassica 2: 176181.

Meena ML and Singh D. 2016. Front line demonstrations of cotton production technology: An impact assessment. J Cotton Res Dev 30: 149-154.

Meena ML and Singh D.2016. Productivity enhancement and gap analysis of moth bean through improved production technologies on farmers' participatory mode. Indian J DrylandAgril Res Dev 31:68-71.

Meena ML and Singh D. 2017. Technological and extension yield gaps in greengram in Pali district of Rajasthan, India. Legume Res 40:187-190.

Morwal BR, Pagaria P, Kantwa SL and Das S.2018. Performance of frontline demonstrations on yield enhancement of cumin in Barmer district of Rajasthan. $\mathbf{J}$ Krishi Vigyan 6: 76-78.

Pathak J. 2018. Yield performance of soybean (Glycine max L.) in Madhya Pradesh. J Krishi Vigyan 6: 253-256.

Prasad C., Chaudhary B.N. and Nayar B.B. 1987: First line transfer of technology project, ICAR, New Delhi, India. Pp 87(2009-10. Rajasthan Agricultural Statistics at a Glance.

Rathore RS, Solanki RL and Sisodia SS. 2016. Impact of frontline demonstrations on cluster bean production in farmers' field. Indian $\mathrm{J}$ Ext Edu Rural Dev 24: 52-54.

RETAIL RESEARCH MUSTARD CROP SURVEY REPORT (2014-15) Disclaimer: http://www.religareonline.com/research/ Disclaimer/Disclaimer_rcl.html

Sawardekar SV, Dhane SS and Jadhav BB. (2003). Frontline demonstration performance of salt-tolerant rice 
varieties in coastal saline soils. IRRN, 28: 73-74.

Singh N and Kumar S. (2017). Yield enhancement and popularization of improved production technologies in wheat through frontline demonstrations. Int J AdvBiol Res 7: 81-84.

Yadav D.B., Kamboj B.K. and Garg R.B. (2004). Increasing the productivity and profitability of sunflower through front line demonstrations in irrigated agroecosystem of eastern Haryana. Haryana J. of Agronomy, 20 (1\&2) : 33-35

Yadav VPS, Kumar $\mathrm{R}$ and Sharma BK. (2016). Boosting up the production of Raya crop through innovative extension mythology. Indian Res $\mathrm{J}$ Ext Edu 16:124-127.

\section{How to cite this article:}

Naresh Kumar Bisen, N. K. Singh and Solanki, R. S. 2020. Productivity Enhancement of Rapeseed-Mustard through Front Line Demonstration in Seoni District of Madhya Pradesh, India. Int.J.Curr.Microbiol.App.Sci. 9(04): 1983-1989.

doi: https://doi.org/10.20546/ijcmas.2020.904.237 